\title{
ANALISIS KESULITAN GURU SD DI LOMBOK UTARA DALAM PENYUSUNAN KARYA ILMIAH
}

\author{
Arif Widodo', Awal Nur Khalifatur Rosyidah², Ida Ermiana ${ }^{3}$, Ashar Pajarungi Anar ${ }^{4}$, Linda \\ Feni Haryati ${ }^{5}$, Setiani Novitasari ${ }^{6}$ \\ Program Studi Pendidikan Guru Sekolah Dasar, Universitas Mataram ${ }^{1,2,3,4,5,6}$ \\ Email: awal_rosyidah@unram.ac.id ${ }^{2}$
}

\begin{abstract}
Abstrak
Guru profesional tidak hanya dituntut untuk mengajar dengan baik, tetapi juga harus memiliki kemampuan menulis yang baik. Karya ilmiah bagi guru merupakan bagian dari pengembangan profesionalisme. Namun demikian tidak sedikit guru yang masih mengalami kesulitan dalam menulis karya ilmiah. Penelitian ini bertujuan untuk menganalisis kesulitan guru dalam menyusun karya ilmiah. Jenis penelitian yang digunakan ialah deskriptif kuantitatif. Lokasi penelitian di SDN 1 dan SDN 5 Pemenang Barat kabupaten Lombok Utara. Penelitian dilaksanakan pada bulan Agustus sampai dengan September 2020. Jumlah guru yang menjadi sampel penelitian adalah 20 guru. Pengumpulan data menggunakan survei. Instrumen yang digunakan berupa angket terbuka dan angket tertutup. Teknik analisis data menggunakan statistik deskriptif. Hasil penelitian menunjukkan bahwa sebagian besar guru merasa kesulitan dalam menyusun karya ilmiah. Faktor penyebabnya antara lain kurangnya motivasi, kurang paham terhadap konsep karya ilmiah, merasa tidak punya waktu, dan rendahnya intensitas menulis karya ilmiah.
\end{abstract}

Kata Kunci : guru profesional, karya ilmiah, pengembangan profesionalisme

\begin{abstract}
Professional teachers are not only required to teach well but also must possess good writing skills. Scientific work for teachers is part of professional development. However, not a few teachers still have difficulty writing scientific papers. This study intends to analyze the difficulties of teachers in compiling scientific papers. This research utilized descriptive quantitative. The research took place at SDN 1 and SDN 5 Pemenang Barat, North Lombok district. The research was conducted from August to September 2020. The number of teachers being the research sample was 20 teachers. Data collection used survey methods. The instruments were in the form of an open questionnaire and a closed questionnaire. The data analysis technique used descriptive statistics. The results showed that most teachers found it difficult to compile scientific papers. The contributing factors included lack of motivation, lack of understanding of the concept of scientific work, the feeling of not having time, and the low intensity of writing scientific papers.
\end{abstract}

Key Words : professional teacher, scientific work, professional development

\section{PENDAHULUAN}

Menjadi guru profesional dewasa ini adalah sebuah keniscayaan. Terlebih lagi di era otonomi daerah guru yang profesional diharapkan dapat meningkatkan kualitas pendidikan di daerah masing-masing. Peran guru sangat penting dalam keberhasilan proses pembelajaran. Mencari guru profesional tidak hanya ditentukan oleh proses rekrutmen guru, tetapi juga ditentukan oleh pembinaan karier ketika menjadi guru. Guru diharapkan dapat mengembangkan profesionalismenya dan memiliki kompetensi profesional pada bidang pembelajaran. Bagaimana guru dapat dikatakan profesional? Guru dapat dikatakan profesional jika memiliki landasan pengetahuan yang kuat, bersertifikat, dan memiliki kesadaran profesional [1].

Guru profesional tidak dapat diciptakan secara instan, tetapi melalui proses yang panjang. Setidaknya, guru harus sering mengikuti pelatihan, seminar dan melakukan penelitian tindakan kelas (PTK). Hal ini sesuai dengan salah satu 
penelitian yang menyebutkan bahwa salah satu cara dalam meningkatkan profesionalisme guru adalah melalui penulisan karya ilmiah [2]. Melalui berbagai kegiatan tersebut seorang guru dapat mengembangkan keahlian mengajar, pengelolaan kelas, disiplin kelas dan aktivitas lain yang bermaanfaat bagi pengembangan kemampuan kognitif siswa. Idealnya guru dapat berperan sebagai fasilitator, pembimbing, penyedia lingkungan belajar yang baik, sebagai model, motivator, sebagai manajer dan agen pengembangan koginitif siswa.

Khusus dalam bidang penelitian tindakan kelas perlu ada perhatian khusus. Hal ini dikarenakan PTK sangat berperan dalam pengembangan profesionalisme guru [3]. Melalui PTK guru dapat memperbaiki proses pembelajaran di kelas, sehingga kualitas pembelajaran meningkat. PTK merupakan salah satu bentuk karya ilmiah yang sering dilakukan oleh guru. Namun demikian, tidak semua guru dapat menulis karya ilmiah ini dengan baik. Bahkan tidak sedikit guru yang terhambat dalam kariernya karena terkendala pada penulisan karya ilmiah [4]. Menulis karya ilmiah masih menjadi hambatan bagi sebagian besar guru [5]. Menulis sebagai salah satu dari keterampilan berbahasa dianggap paling sulit jika dibandingkan dengan keterampilan berbahasa lainnya [6]. Hal ini terbukti dengan masih rendahnya tingkat publikasi ilmiah guru di Indonesia [7].

Karya ilmiah merupakan karya tulis yang disusun berdasarkan hasil penelitian dan prosedur ilmiah [8]. Menulis merupakan salah satu upaya pemecahan yang paling efektif. Seseorang yang pandai dalam menulis akan mendapatkan penghargaan sosial dan intelektual yang besar [9]. Tahapan menulis diawali dengan membaca [10]. Tidak hanya sekedar membaca dasar tetapi juga membaca pemahaman hingga menceritakan kembali dalam bentuk tulisan. Menulis sebagai sebuah keterampilan membutuhkan proses [11]. Artinya adalah kemampuan menulis tidak datang secara tiba-tiba tetapi harus melalui proses pelatihan dan bimbingan. Tanpa adanya pelatihan kemampuan menulis tidak akan berkembang. Terlebih lagi dalam menulis karya tulis ilmiah bagi guru tidak hanya membutuhkan latihan tetapi juga pembiasaan dan mempunyai komitmen untuk memecahkan problematika dalam pembelajaran.

Jenis karya ilmiah yang paling banyak dibutuhkan oleh seorang guru adalah jenis penelitian PTK. Banyak terdapat permasalahan yang harus dipecahkan oleh guru melalui sebuah karya tulis PTK. Namun demikian kemampuan para guru dalam menyusun PTK masih tergolong rendah. Rata-rata guru belum memiliki bekal yang cukup terkait dengan teknik penulisan PTK [12]. Permasalahan semacam ini juga dialami oleh sebagian besar guru di kabupaten Lombok Utara. Sejumlah guru di daerah ini bahkan tidak tahu apa yang akan ditulis untuk menjadi sebuah karya tulis [13]. Identifikasi permasalahan, teknik penulisan dan hal-hal lain terkait dengan penulisan karya ilmiah belum banyak dipahami.

Berdasarkan permasalahan di atas, perlu diadakan penelitian terkait dengan kesulitan yang dialami para guru dalam menulis karya ilmiah. Terdapat beberapa penelitian terdahulu yang mengkaji tentang penulisan karya ilmiah antara lain: penelitian yang mengkaji tentang pemahaman guru terhadap penulisan karya ilmiah [14]. Dalam penelitian tersebut diungkapkan bahwa pemahaman guru terhadap penulisan karya ilmiah masih rendah. Penelitian selanjutnya mengkaji tentang kesulitan guru SMA dalam penulisan karya ilmiah [2]. Berdasarkan kajian tersebut bentuk kesulitan guru dapat diklasifikasikan menjadi dua bagian besar 
yaitu faktor internal dan faktor eksternal. Faktor internal yang ditemukan antara lain motivasi rendah, tidak memiliki waktu, teknik penulisan, teknik pengumpulan data, dan penguasaan teknologi yang masih kurang. Faktor eksternal yang ditemukan antara lain referensi masih terbatas, jasa penulisan karya ilmiah mudah ditemukan, MGMP kurang berfungsi dan sosialisasi dari sekolah masih kurang.

Beberapa penelitian terdahulu banyak menyoroti terkait dengan kesulitan menulis karya ilmiah bagi guru tingkat SMA. Pada penelitian ini yang dikaji adalah kesulitan menulis karya ilmiah bagi guru sekolah dasar. Penelitian ini bertujuan untuk mengetahui apa saja faktor yang menghambat guru sekolah dasar dalam menulis karya ilmiah. Melalui penelitian ini diharapkan faktor-faktor yang menyebabkan guru kesulitan menulis karya ilmiah dapat terungkap. Manfaat dari penelitian ini antara lain dapat memberikan rekomendasi kebijakan kepada pihak yang terkait. Hal ini perlu dilakukan agar upaya pemecahan masalah dari pihak yang terkait dapat tepat sasaran.

\section{METODE}

Penelitian ini didesain dalam bentuk penelitian kuantitatif dengan pendekatan deskriptif. Subjek penelitian adalah guru sekolah dasar. Jumlah responden yang terkumpul sebanyak 20 guru. Lokasi penelitian di SDN 1 dan 5 Pemenang Barat. Penelitian dilakukan pada bulan Agustus sampai dengan September 2020. Tahapan penelitian diawali dengan studi pendahuluan, pembuatan instrumen penelitian, pengumpulan data, analisis data dan penarikan kesimpulan [15]. Pengumpulan data menggunakan survei. Instrumen yang digunakan adalah angket. Sebelum dilakukan pengambilan data terlebih dahulu dilakukan validasi terhadap instrumen penelitian. Berdasarkan uji validitas expert judgment instrumen dinyatakan baik dan layak digunakan untuk pengumpulan data. Berikut ini dapat disajikan indikator yang digunakan untuk menjaring data penelitian.

\section{Tabel 1. Indikator Penelitian}

\begin{tabular}{cl}
\hline Indikator & \multicolumn{1}{c}{ Bentuk Pertanyaan } \\
\hline Intensitas & Apakah bapak/ibu guru pernah \\
Menulis & menulis karya ilmiah? \\
Motivasi & Apakah bapak/ibu guru bersemangat \\
Menulis & untuk menulis karya ilmiah? \\
Waktu & Apakah bapak/ibu guru mempunyai \\
menulis & waktu yang cukup untuk menulis \\
& karya ilmiah? \\
Pemahaman & Apakah bapak/ibu telah memahami \\
konsep & konsep penulisan karya ilmiah? \\
menulis & \\
Pelatihan & Apakah bapak/ibu pernah mengikuti \\
menulis & pelatihan menulis karya ilmiah? \\
\hline & \multicolumn{2}{c}{ Sumber: Modifikasi Peneliti }
\end{tabular}

Terdapat dua jenis angket yang digunakan yaitu angket terbuka dan angket tertutup. Angket terbuka dikenal juga dengan angket tidak terstruktur. Angket terbuka disajikan secara sederhana, responden dapat menjawab pertanyaan sesuai dengan keadaan yang dialaminya. Berbeda dengan angket tertutup, responden telah disediakan jawaban. Responden dapat memilih jawaban yang paling sesuai dengan keadaan yang dialaminya, oleh karena itu angket tertutup disebut juga dengan angket terstruktur [16]. Penggunaan angket terbuka bertujuan untuk mendapatkan data secara detail dari responden, sedangkan angket tertutup digunakan untuk mengetahui persepsi responden sesuai dengan indikator yang ditetapkan oleh peneliti. Analisis data menggunakan statistik deskriptif. Tahapan analisis data antara lain pengumpulan data melalui Google Form, tabulasi data, penyajian data, interpretasi data dan penarikan kesimpulan.

\section{HASIL DAN PEMBAHASAN}

Terdapat enam pertanyaan yang diberikan kepada responden. Lima pertanyaan berbentuk angket tertutup dan satu pertanyaan berbentuk angket terbuka. 
Berikut ini dapat disajikan hasil survei menggunakan angket tertutup. Pertanyaan pertama yang diberikan kepada responden adalah "apakah bapak/ibu guru pernah menulis karya ilmiah?". Jawaban responden dapat disajikan pada diagram berikut.

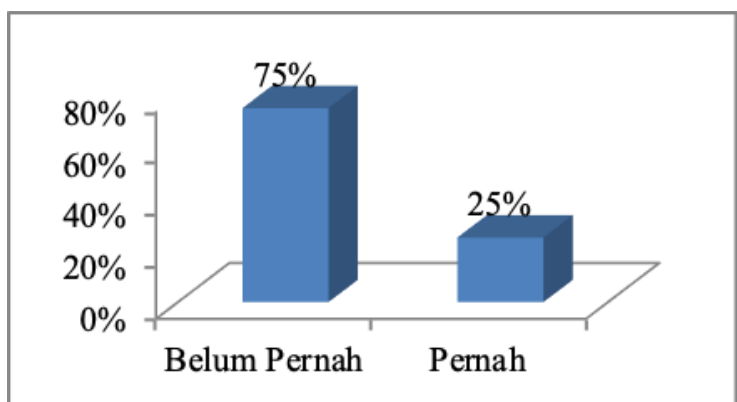

Gambar 1. Intensitas Menulis

Pada Gambar 1 dapat diketahui bahwa intensitas menulis para guru masih tergolong rendah. Dari 20 responden hanya $25 \%$ saja yang pernah menulis karya ilmiah, selebihnya belum pernah menulis karya tulis ilmiah.

Pertanyaan kedua yang diberikan kepada responden adalah "Apakah bapak/ibu guru bersemangat untuk menulis?". Jawaban responden dapat disajikan pada diagram berikut.

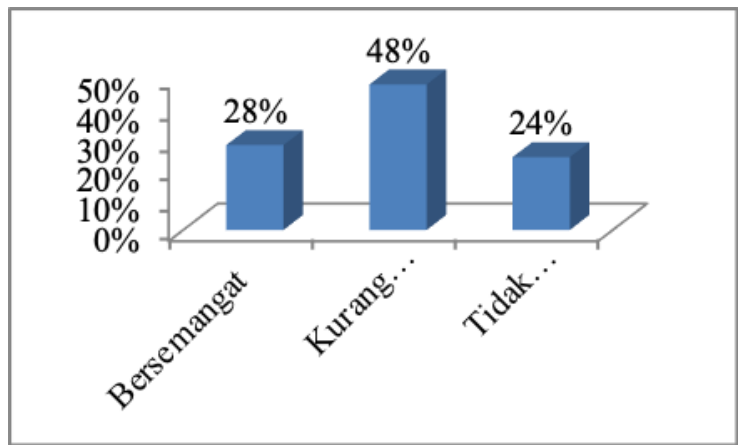

\section{Gambar 2. Semangat Menulis}

Aspek kedua yang dipertanyaan berkaitan dengan motivasi dalam menulis. Berdasarkan pada Gambar 2, dapat diketahui bahwa jumlah guru yang merasa bersemangat untuk menulis hanya $28 \%$, sedangkan $48 \%$ merasa kurang semangat dan $24 \%$ mengaku tidak bersemangat sama sekali. Hal ini menunjukkan bahwa motivasi guru dalam menulis karya ilmiah dapat dikategorikan masih kurang.

Pertanyaan ketiga yang diberikan kepada responden adalah "Apakah bapak/ibu guru mempunyai waktu yang cukup untuk menulis karya ilmiah?". Jawaban responden dapat disajikan pada diagram berikut.

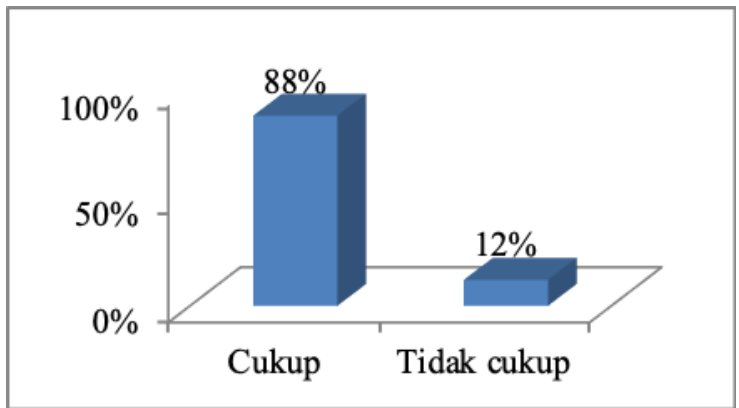

Gambar 3. Ketersediaan Waktu

Terkait dengan waktu responden mengaku masih memiliki cukup waktu untuk menulis. Hal ini dapat terlihat pada Gambar 3 yang menunjukkan bahwa $88 \%$ responden mengaku masih memiliki waktu yang cukup untuk menulis, sedangkan yang mengaku tidak cukup hanya $12 \%$. Data ini menunjukkan bahwa pada hakikatnya para guru masih memiliki waktu luang untuk menulis.

Pertanyaan keempat yang diberikan kepada responden adalah "Apakah bapak/ibu telah memahami konsep penulisan karya ilmiah?". Jawaban responden dapat disajikan pada diagram berikut.

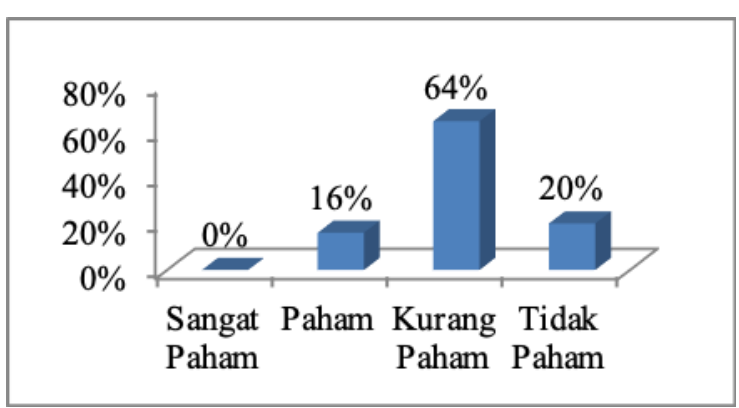

Gambar 4. Pemahaman Konsep 
Berdasarkan pada Gambar 4, dapat diketahui bahwa tingkat pemahaman guru terhadap konsep penulisan karya tulis ilmiah masih rendah. Konsep karya tulis ilmiah berkaitan dengan teori dan metodologi dalam penyusunan karya ilmiah. Pada aspek pemahaman konsep tidak ada guru yang merasa sangat paham terhadap konsep karya tulis ilmiah. Hanya $16 \%$ guru yang merasa telah paham dengan konsep karya tulis ilmiah. Sisanya sebanyak $64 \%$ merasa kurang paham dan $20 \%$ tidak paham sama sekali.

Pertanyaan kelima yang diberikan kepada responden adalah "Apakah bapak/ibu guru pernah mengikuti pelatihan menulis karya ilmiah?". Jawaban responden dapat disajikan pada diagram berikut.

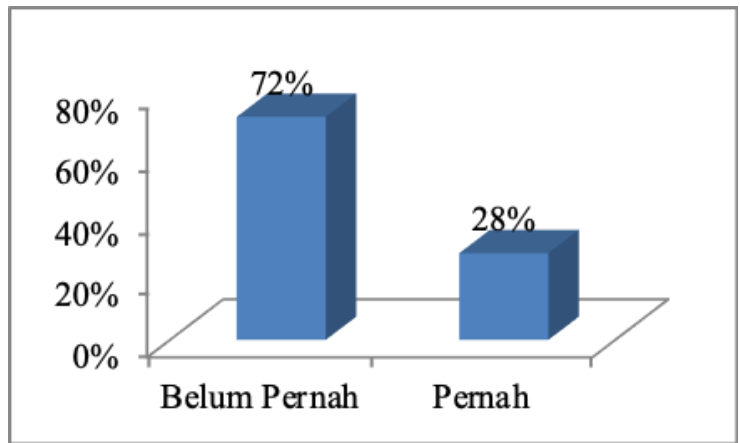

Gambar 5. Intensitas Pelatihan

Intensitas mengikuti pelatihan penting ditanyakan karena berkaitan dengan penguasaan para guru dalam memahami teknik penulisan karya tulis ilmiah. Berdasarkan gambar 5 dapat diketahui bahwa jumlah guru yang pernah mengikuti pelatihan lebih sedikit daripada yang sudah mengikuti pelatihan. Jumlah guru yang mengaku pernah mengikuti pelatihan hanya $28 \%$, sedangkan sisanya sebanyak $72 \%$ mengaku belum pernah. Hal ini menunjukkan bahwa intensitas guru dalam mengikuti pelatihan penulisan karya ilmiah masih rendah.

Pertanyaan yang diberikan kepada responden pada angket terbuka bertujuan untuk mengetahui kesulitan yang dialami guru dalam menulis karya ilmiah. Melalui angket terbuka diharapkan mendapatkan data yang lebih detail dari masing-masing guru. Pertanyaan yang diberikan adalah apa kesulitan yang bapak/ibu guru alami dalam menulis karya ilmiah. Berdasarkan angket terbuka yang telah diberikan terdapat jawaban yang cukup bervariasi dari responden. Untuk mempermudah analisis data pada angket terbuka dilakukan pengelompokan terhadap jawaban responden. Berdasarkan jawaban responden tersebut dapat dikelompokkan menjadi tiga kelompok, antara lain: Pertama, responden mengungkapkan bahwa faktor penyebab kesulitan menulis karya ilmiah adalah kurangnya pengetahuan dan pemahaman tentang karya ilmiah. Setidaknya terdapat 17 responden yang menyatakan jawaban serupa dengan jawaban di atas. Kedua, responden menyatakan bahwa penyebab kesulitan dalam menulis karena motivasi menulisnya rendah, dan tidak memiliki waktu yang cukup dalam menulis karya tulis ilmiah. Ketiga, kelompok yang menyatakan bahwa faktor penyebab kesulitan dalam menulis karya ilmiah adalah terbatasnya bahan bacaan sebagai sumber referensi dalam menulis karya ilmiah.

Berdasarkan paparan data dari angket terbuka dan angket tertutup dapat dipahami bahwa terdapat beberapa faktor utama yang menyebabkan para guru mengalami kesulitan dalam menyusun karya ilmiah. Faktor pertama adalah intensitas menulis. Menulis pada dasarnya adalah keterampilan dasar. Namun demikian jika tidak diasah kemampuan menulis akan tumpul. Implikasinya adalah tidak dapat menemukan ide-ide kreatif dalam menulis. Hal ini sesuai dengan salah satu penelitian yang menyatakan bahwa salah satu kunci keberhasilan dalam menulis adalah dengan tekun berlatih [17]. Melalui tekun berlatih 
kemampuan pengembangan ide, pemecahan masalah dan keterampilan merangkai kata dapat meningkat.

Faktor kedua yang menjadi penghambat para guru dalam menulis karya ilmiah berkaitan dengan motivasi. Hanya sedikit guru yang merasa bersemangat dalam menulis karya tulis ilmiah. Salah satu penyebabnya adalah adanya anggapan bahwa menulis itu sulit. Berdasarkan pada sebuah penelitian terungkap bahwa menulis dianggap sebagai aktivitas yang membosankan [18]. Pada dasarnya menulis merupakan aktivitas yang menggabungkan kemampuan berbahasa dan talenta yang dimilikinya [19]. Hal inilah yang membuat seseorang yang merasa tidak memiliki bakat menulis enggan untuk menulis. Implikasinya adalah motivasi menulis menjadi semakin rendah. Padahal kemampuan menulis tidak hanya tergantung pada bakat, tetapi juga pada kemauan dan ketekunan dalam berlatih.

Faktor ketiga yang dituding sebagai penyebab para guru mengalami kesulitan dalam menulis adalah tidak punya waktu. Berdasarkan pada data penelitian alasan waktu tidak dapat menjadi alasan yang mutlak, karena berdasarkan survei yang dilakukan hanya sedikit guru yang mengaku tidak memiliki waktu. Hal ini bermakna bahwa pada dasarnya guru masih memiliki waktu yang cukup untuk menulis, hanya saja faktor kemauan dan kemampuan yang harus ditingkatkan.

Faktor keempat yang menjadi kendala guru adalah rendahnya pemahaman konsep guru terhadap karya tulis ilmiah. Tingkat pemahaman yang rendah berkorelasi terhadap rendahnya kemampuan guru dalam menyusun karya tulis. Konsep karya tulis ilmiah berkaitan dengan metodologi, sistematika penulisan, dan teknik penulisan. Bahkan sebagian besar guru masih mengalami kesulitan dalam kemampuan dasar menulis ilmiah, salah satunya bagaimana teknik menulis daftar pustaka. Kemampuan menulis daftar pustaka juga perlu mendapat perhatian mengingat sebuah karya tulis tidak dapat dikatakan ilmiah jika tidak dilengkapi dengan daftar pustaka [20]. Rendahnya tingkat pemahaman konsep penulisan karya ilmiah salah satunya disebabkan oleh rendahnya intensitas dalam mengikuti pelatihan. Berdasarkan survei yang dilakukan hanya sedikit guru yang mengaku pernah mengikuti pelatihan menulis karya tulis ilmiah. Hal ini sesuai dengan sebuah kajian yang menyatakan bahwa pelatihan menulis memiliki kontribusi yang cukup besar dalam meningkatkan kemampuan menulis karya ilmiah para guru [21].

Faktor kelima yang menjadi permasalahan adalah kurangnya referensi sebagai literature penulisan karya ilmiah. Hal ini dapat dipahami bahwa membaca merupakan unsur kebahasaan yang paling mendasar. Modal utama sebagai penulis adalah membaca. Tanpa membaca seseorang akan kesulitan dalam menemukan ide dan tidak memiliki gambaran tentang penelitian terdahulu yang telah dilakukan. Terdapat suatu ungkapan bahwa menulis yang baik harus diawali dengan membaca yang baik. Artinya adalah intensitas membaca harus ditingkatkan agar kualitas tulisan yang didapatkan menjadi lebih baik. Melalui membaca karya terdahulu dengan baik karya tulis dapat terhindar dari plagiarisme, karena dengan membaca secara detail penulis dapat menempatkan posisi posisi karyanya di tengah penelitian terdahulu yang telah dilakukan. Hal ini penting dilakukan mengingat permasalahan plagiarisme dan indeks similarity merupakan permasalahan yang paling disoroti dalam dunia penulisan ilmiah [22]. Kedua aspek ini berkaitan dengan kejujuran dan novelty dari sebuah karya. 
Pengkategorian dan pemetaan masalah dari referensi sangat penting dilakukan [23]. Dalam sebuah penelitian disebutkan bahwa menemukan dan menjaring literatur yang relevan membutuhkan keahlian [24]. Permasalahannya guru menganggap mencari referensi itu sulit. Keterbatasan referensi dalam perspektif guru perlu diubah. Seiring dengan berkembangnya teknologi informasi alasan kurang referensi tidak dapat dijadikan alasan. Hal ini dikarenakan telah banyak tersedia jurnal ilmiah secara online yang dapat diakses kapan saja. Permasalahan yang terjadi sesungguhnya terletak pada kemampuan guru dalam mengakses literatur. Keterbatasan pengetahuan guru tentang jurnal ilmiah menjadi ujung pangkalnya. Masih banyak guru yang menganggap bahwa literatur harus berupa buku yang dicetak. Implikasinya jika tidak ada jurnal versi cetak dianggap tidak ada referensi. Berdasarkan fenomena ini pelatihan menulis bagi guru merupakan salah satu solusi yang dapat dilakukan. Tujuannya agar pengetahuan guru terhadap seluk beluk penulisan karya ilmiah dapat meningkat sehingga kemampuan menulis karya ilmiahnya juga akan mengalami peningkatan.

\section{SIMPULAN}

Berdasarkan hasil penelitian dan pembahasan dapat ditarik simpulan bahwa terdapat tiga faktor utama yang menghambat guru dalam menulis karya ilmiah antara lain kurangnya pemahaman tentang konsep penulisan karya ilmiah, kurangnya motivasi dan rendahnya intensitas menulis. Selain itu, ada sebagian kecil guru yang mengaku tidak cukup memiliki waktu untuk menulis dan kurangnya referensi yang dimiliki. Solusi yang dapat ditawarkan untuk mengatasi permasalahan bagi guru adalah dengan meningkatkan intensitas pelatihan menulis bagi para guru, mengingat pelatihan menulis karya ilmiah belum banyak dilakukan terutama di daerah pelosok.

\section{DAFTAR PUSTAKA}

[1] M. Anwar. Menjadi Guru Profesional. Jakarta: Prenada Media, 2018.

[2] L. Noorjannah. "Pengembangan Profesionalisme Guru Melalui Penulisan Karya Tulis Ilmiah bagi Guru Profesional di SMA Negeri 1 Kauman Kabupaten Tulungagung". J. Humanit., vol. 10, no. 1, p. 11406 , 2014.

[3] N. Marlena, R. Dwijayanti, F. D. Patrikha, dan P. Parjono. "Pelatihan Penulisan Karya Tulis Ilmiah (KTI) bagi Guru SMA Swasta di Sidoarjo". J. ABDI, vol. 2, no. 2, p. 45, Apr. 2017.

[4] I. Sodiq, A. Suryadi, dan T. A. Ahmad. "Program Guru Menulis: Upaya Peningkatan Kompetensi Profesional Guru Sejarah dalam Penulisan Karya Ilmiah di Kabupaten Semarang". Rekayasa, vol. 12, no. 1, pp. 42-47, 2014.

[5] Y. Yulhendri, J. E. Marna, dan O. Oknaryana. "Analisis Kemampuan Menulis Karya Ilmiah Guru Ekonomi di Kabupaten Pasaman Barat". J. Inov. Pendidik. Ekon., vol. 8, no. 1, p. 56, Apr. 2018.

[6] I. Gunawan, T. Triwiyanto, dan D. E. Kusumaningrum. "Pendampingan Penulisan Artikel Ilmiah bagi Para Guru Sekolah Menengah Pertama”. Abdimas Pedagog. J. Ilm. Pengabdi. Kpd. Masy., vol. 1, no. 2, pp. 128135, 2018.

[7] B. A. Pribadi dan R. Delfy. "Implementasi Strategi Peta Konsep (Concept Mapping) dalam Program Tutorial Teknik Penulisan Artikel Ilmiah bagi Guru". J. Pendidik. Terbuka Dan Jarak Jauh, vol. 16, no. 2, pp. 76-88, 2015.

[8] Firman. Terampil Menulis Karya 
Ilmiah. Makasar: Penerbit Aksara Timur, 2015.

[9] R. Bruning and C. Horn. "Developing Motivation to Write". Educ. Psychol., vol. 35, no. 1, pp. 25-37, Mar. 2010.

[10] C. Chomsky. "Write First, Read Later". Child. Educ., vol. 47, no. 6, pp. 296-299, Mar. 2013.

[11] A. C. Ventura, N. Scheuer, and J. I. Pozo. "Elementary School Children's Conceptions of Teaching and Learning to Write as Intentional Activities". Learn. Instr., vol. 65, no. February, p. 101249, Feb. 2020.

[12] I. Ilfiandra, U. Suherman, S. N. Akhmad, A. Budiamin, dan S. Setiawati. "Pelatihan dan Pendampingan Penulisan Karya Tulis Ilmiah bagi Guru SD". $J$. Pengabdi. Pada Masy., vol. 1, no. 1, pp. 70-81, Dec. 2016.

[13] A. N. K. Rosyidah, I. Ermiana, A. Widodo, L. F. Haryati, S. Novitasari, dan A. P. Anar. "Pelatihan dan Pendampingan Penulisan Karya Tulis Ilmiah untuk Guru di SDN 1 dan 5 Pemenang Lombok Utara". $J$. Pendidik. dan Pengabdi. Masy., vol. 3, no. 4, pp. 240-246, 2020.

[14] B. Sumardjoko. "Pemetaan Kemampuan Guru dalam Penulisan Karya Ilmiah". in The 5th Urecol Proceeding, 2017, no. February, pp. 191-196.

[15] I. Hermawan. Metodologi Penelitian Pendidikan: Kuantitatif, Kualitatif \& Mixed Methode. 1st ed. Kuningan: Hidayatul Quran Kuningan, 2019.

[16] Riduwan. Metode \& Teknik Penyusunan Proposal Penelitian. Bandung: Alfabeta, 2014.

[17] S. Halidjah. "Peningkatan
Keterampilan Menulis Karya Ilmiah Melalui Lesson Study". BAHTERA J. Pendidik. Bhs. dan Sastra, vol. 14, no. 1, pp. 47-54, 2015.

[18] Awalludin dan Y. Lestari. "Pengembangan Modul Menulis Makalah pada Mata Kuliah Pengembangan Keterampilan Menulis". J. Bind. Sastra, vol. 1, no. 2, pp. 121-130, 2017.

[19] R. Rahmiati. "Problematika Mahasiswa dalam Menulis Karya Ilmiah". J. Adab., vol. 8, no. 2, pp. 160-175, 2013.

[20] S. Widiastuti. "Kemampuan Menulis Daftar Rujukan Mahasiswa Program Studi Pendidikan Guru Sekolah Dasar (PGSD) Universitas Islam Balitar (UNISBA)". KONSTRUKTIVISME, vol. 11, no. 1, pp. 32-41, 2019.

[21] E. N. Aisyah dan P. Mahanani. "Pelatihan Menulisan Artikel Ilmiah bagi Guru Sekolah Dasar dan Taman Kanak-Kanak Kecamatan Tajinan Kabupaten Malang". Abdimas Pedagog. J. Ilm. Pengabdi. Kpd. Masy., vol. 1, no. 1, pp. 22-26, 2017.

[22] K.-C. Chou. "Using Similarity Software to Evaluate Scientific Paper Quality Is a Big Mistake". Nat. Sci., vol. 12, no. 03, pp. 42-58, 2020.

[23] M. Al-Ruithe, E. Benkhelifa, and K. Hameed. "A Systematic Literature Review of Data Governance and Cloud Data Governance". Pers. Ubiquitous Comput., vol. 23, no. 56, pp. 839-859, Nov. 2019.

[24] S. Marcos-Pablos and F. J. GarcíaPeñalvo. "Information Retrieval Methodology for Aiding Scientific Database Search". Soft Comput., vol. 24, no. 8, pp. 5551-5560, Apr. 2020. 